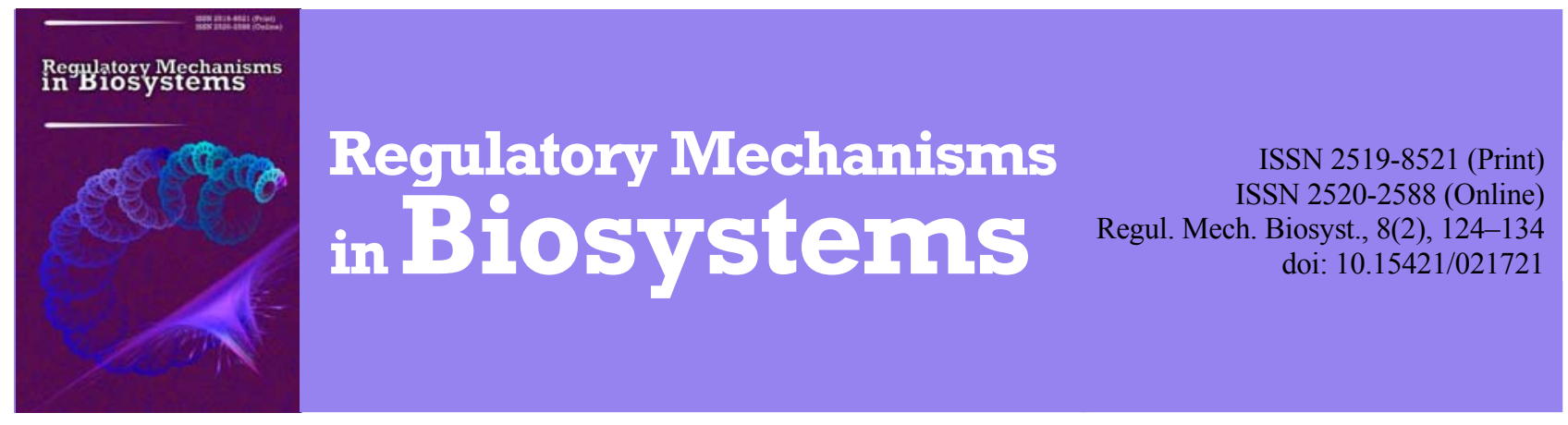

\title{
Mechanism of changing adaptation potential and morpho-biochemical parameters of erythrocytes in students with different modes of daily activity after physical loading
}

S. L. Popel**, B. M. Mytckan*, E. Y. Lapkovskyi*, B. P. Lisovskyi*, Y. N. Yatciv*, N. O. Zemskaya*, R. S. Tyagur*, T. S. Mytckan*, I. M. Tkachivska*, L. V. Kovalchuk*, O. N. Leschak*, R. I. Fayichak*, I. V. Melnik**, G. D. Markiv***

*Precarpathian National University named after V. Stefanik, Ivano-Frankivsk, Ukraine

**Ivano-Frankivsk National Medical University, Ivano-Frankivsk, Ukraine

***Central City Hospital, Ivano-Frankivsk, Ukraine

Article info

Received 24.02.2017

Received in revised form 21.03.2017

Accepted 23.03.2017

Precarpathian National University named after $V$. Stefanik, Shevchenko Str., 57

Ivano-Frankivsk, 76018, Ukraine

Ivano-Frankivsk National

Medical University

Galitcka Str., 2,

Ivano-Frankivsk, 76025, Ukraine

Central City Hospital,

Hetman Mazepa Str., 114,

Ivano-Frankivsk, 76025, Ukraine

Tel.: +38-097-874-14-46.

E-mail:popelsergij@gmail.com
Popel', S. L., Mytckan, B. M., Lapkovskyi, E. Y., Lisovskyi, B. P., Yatciv, Y. N., Zemskaya, N. O., Tyagur, R. S., Mytckan, T. S., Tkachivska, I. M., Kovalchuk, L. V., Leschak, O. N., Fayichak, R. I., Melnik, I. V., \& Markiv, G. D. (2017). Mechanism of changing adaptation potential and morpho-biochemical parameters of erythrocytes in students with different modes of daily activity after physical loading. Regulatory Mechanisms in Biosystems, 8(2), 124-134. doi:10.15421/021721

The aim of this work was to identify morpho-functional and biochemical changes in erythrocytes in students with different daily educational -training regimens after dosed physical exertion. The study involved 50 male students aged 20-22 years who study at the Faculty of Physical Education and Sports. Of these, 25 were untrained students (control group) and 25 were students studying for the highest sports qualification who were engaged in sports in which training was conducted to improve overall endurance (skiing, biathlon, long-distance running). At the end of the school year, all students were required to carry out a single session involving physical loading of maximum intensity on a veloergometer. According to the results of the questionnaire, it was found that the combination of intensive training and training processes caused a mismatch between the functional capabilities of the students' and athletes' biological systems and the increased volume and intensity of their psycho-physical loading, which is closely correlated with a decrease in their level of physical health. In the blood of untrained students, under the influence of dosed physical activity, reversibly altered forms of erythrocyte appeared, which accounted for $2.0 \%$ of the total number of erythrocytes. In the morphological study of student athletes, an increase in the content of reversibly and irreversibly altered erythrocytes was observed, the number of which exceeded $2.0 \%$ of the total number of erythrocytes. In individual student athletes echinocytes with small-focal microdefects of the outer membrane were observed in the peripheral blood, as well as acanthocytes and stomatocytes, which have low resistance to acid hemolysis. The mechanism of this phenomenon is a decrease in the activity of glucose-6-phosphate dehydrogenase and glutathione reductase, which leads to a deficiency of reduced glutathione in erythrocytes. Such cells under the influence of oxidizing agents quickly undergo lysis, which is manifested by a violation of their structural integrity. This can lead to the development of "anemia of loading", which is manifested by a decrease in the concentration of hemoglobin and the number of erythrocytes with their morphometric recalibration due to the appearance of macro-microcytic forms. The presence of such changes can adversely affect both the athletic performance and the state of health of students. This requires appropriate correction of the training process, as well as the development and timely application of adequate measures aimed at eliminating the development of the pathological process and eliminating possible undesirable consequences.

Keywords: student-athletes; physical loading; adaptive potential; somatic health; biochemical indicators

\section{Механізм зміни адаптаційного потенціалу та морфобіохімічні параметри еритроцитів у студентів із різним режимом дня після фізичного навантаження}

\author{
С. Л. Попель*, Б. М. Мицкан*, Е. І. Лапковський*, Б. П. Лісовський*, Я. М. Яців*, \\ Н. О. Земська*, Р. С. Тягур*, Т. С. Мицкан*, І. М. Ткачівська*, Л. В. Ковальчук*, \\ О. М. Лещак*, Р. І. Файчак*, І. В. Мельник**, Г. Д. Марків*** \\ *Прикарпатський начіональний університет імені Василя Стефаника, Івано-Франківськ, Украӥна \\ **Івано-Франківський національний медичний університет, Івано-Франківськ, Украйна \\ ***Центральна міська лікарня, Івано-Франківськ, Україна
}


Виявлено взааємозв'язок між рівнем адаптаційного потенціалу та морфобіохімічними змінами еритроцитів у студентів із різним навчально-тренувальним режимом дня після дозованого фізичного навантаженням. У дослідженні брали участь 50 студентів чоловічої статі віком 20-22 роки, які навчаються на факультеті фізичного виховання та спорту. 3 них 25 нетренованих (контрольна група) і 25 студентів-спортсменів вищої спортивної кваліфікації, які займалися аеробними видами спорту (лижний спорт, біатлон, тріатлон). У кінці навчального року юнаків піддавали впливу одноразового фізичного навантаження максимальної аеробної потужності на велоергометрі. У крові нетренованих студентів за впливу дозованого фізичного навантаження з'являються близько 2\% зворотно змінених форм еритроцитів. Під час морфологічного дослідження у студентів-спортсменів спостерігали підвищення вмісту зворотно та незворотно змінених еритроцитів, кількість яких перевищує 2\% їх загальної кількості. В окремих спортсменів у периферійній крові спостерігали ехіноцити 3 дрібновогнищевими мікродефектами зовнішньої мембрани, а також виявили аканто- і стоматоцити, які мають низьку стійкість до кислотного гемолізу. Механізм такого явища полягає у зниженні активності глюкозо-6-фосфат дегідрогенази та глутатіонредуктази, що спричиняє дефіцит відновленого глутатіону в еритроцитах. Такі клітини за впливу окисних агентів швидко піддаються лізису, що проявляється порушенням їх структурної цілісності. Це може спричинити розвиток «анемії навантаження», яка проявляється зниженням концентрації гемоглобіну та кількості еритроцитів з їх морфометричним перекалібруванням за рахунок появи макро-мікроцитарних форм. Наявність таких змін може негативно впливати як на спортивні результати, так і на стан здоров'я студентів, що вимагає відповідної корекції навчально-тренувального процесу, а також розроблення та своєчасного застосування адекватних заходів, спрямованих на усунення розвитку патологічного процесу та ліквідацію можливих негативних наслідків.

Ключові слова: студенти-спортсмени; фізичне навантаження; адаптаційний потенціал; соматичне здоров’я; біохімічні показники

\section{Вступ}

Сучасні умови навчання на факультеті фізичного виховання та спорту висувають до студентів певні вимоги щодо адаптаційних здібностей організму за екстремальної діяльності i, перш за все, за поєднаних значних фізичних і психоемоційних (навчальних) навантажень (Brock et al., 2009; Kang, 2016). При цьому багато студентів поєднують навчання 3 професійними занятями спортом різного спрямування. На думку багатьох авторів (Lorente-Catalan and Kirk, 2015; Zhu, 2015), тільки оптимальний морфофункціональний стан біологічних систем організму студентів може стати основою для успішної навчальної та професійної діяльності у спорті. Надмірні тренувальні та змагальні навантаження, насиченість та інтенсифікація графіка навчального процесу створюють негативні передумови до розвитку своєрідного передпатологічного стану, що часто спостерігається у студентів у вигляді зниження рівня адаптаційного потенціалу. Існує низка екзо- та ендогенних чинників, які можуть істотно обмежувати фізичну та розумову працездатність студентів (Lambert, 2016). Іноді той чи інший чинник, який викликав обмеження різних видів працездатності, як правило, залишається непоміченим, але через деякий час він викликає дисбаланс основних функціональних систем організму, що негативно позначається на стані соматичного здоров'я студентів. Маніфестація та генералізація цих причин може спричинити розвиток патологічних змін в організмі студентів. Своєчасне виявлення чинників, що лімітують фізичну працездатність, уміння усувати ці чинники та адекватне застосування засобів корекції допомагають не тільки досягти високих результатів одночасно в навчанні та спорті, а й зберегти соматичне здоров'я студентів (Barker et al., 2016).

Поєднана тренувально-змагальна та навчальна діяльність часто супроводжується роботою, коли у функціонально навантажених тканинах збільшується кисневий запит, тим самим підвищується навантаження на систему забезпечення організму киснем. У разі невідповідності між доставкою та підвищеною потребою тканин у кисні розвивається гіпоксія навантаження (González-Alonso, 2012; Mairbäurl, 2013). Дефіцит або порушення функціонування еритроцитів за рахунок їх структурних пошкоджень - один із чинників, що сприяє розвитку такої гіпоксії (Tan et al., 2010; Bianchini and Wright, 2013; Mohanty et al., 2014). Такі зміни структури еритроцитів у поєднанні 3 гіпоксією навантаження різко знижують фізичну, а потім i розумову працездатність, оскільки як і гіпоксія навантаження, так і гіпоксія за гіпокінезії, що супроводжує навчальний процес, у комплексі посилюють кисневе голодування тканин організму.

Визначення рівня адаптаційного потенціалу та 3'ясування особливостей функціонування киснево-транспортних систем організму студентів із різним режимом навчальної та тренувально-змагальної діяльності та своєчасна корекція виявлених змін необхідні для нівелювання несприятливої дії поєднаних інтенсивних фізичних і навчальних навантажень, а також чин- ників, що лімітують фізичну та розумову працездатність. Це, у свою чергу, дозволить оптимізувати рівень психофізичного стану студентів протягом усього періоду навчання. Незважаючи на актуальність такого роду досліджень, вивчення цієї проблеми не проводилось, що визначило актуальність і мету нашої роботи.

Мета цього дослідження - оцінити адаптаційний потенціал та морфобіохімічні параметри еритроцитів у студентів із різним навчально-тренувальним режимом дня після дозованого фізичного навантаження.

\section{Матеріал і методи досліджень}

В обстеженні брали участь 50 студентів чоловічої статі віком 20-22 роки, які навчаються на факультеті фізичного виховання та спорту ДВНЗ «Прикарпатський національний університет імені Василя Стефаника». Із них 25 студентів, які віднесені до контрольної групи, були практично здорові та не залучені до спеціалізованих спортивних тренувань. До складу експериментальної групи зараховано 25 студентів вищої спортивної кваліфікації, які займалися аеробними видами спорту (лижний спорт, біатлон, тріатлон). У кінці навчального року всім студентам рекомендували провести одноразове фізичне навантаження потужністю 2,4 $\pm 0,10$ ВТ/кг на велоергометрі «Ketler» (Німеччина).

Для оцінки адаптаційного потенціалу вимірювали рівень артеріального тиску та частоту серцевих скорочень. Кількісне значення цього показника визначали за формулою: АП $=0,011 \times$ $\mathrm{ЧCC}+0,014 \times \mathrm{AT}_{\text {сист. }}+0,008 \times \mathrm{AT}_{\text {діаст. }}+0,014 \times \mathrm{B}+0,009 \times \mathrm{P}-$ $0,009 \times \mathrm{L}-0,27$, де ЧСС - частота серцевих скорочень (уд./Хв); $\mathrm{AT}_{\text {сист. }}$ i $\mathrm{AT}_{\text {діаст. }}$ - систолічний і діастолічний артеріальний тиск відповідно (мм рт. ст.), В - вік (років), Р - маса тіла (кг), L довжина тіла (см).

Величина адаптаційного потенціалу служила критерієм резистентності студентів до фізичного навантаженя в межах: до 1,60 бала - дуже висока стійкість до фізичного навантаження, 1,61-1,90 - висока стійкість, 1,91-2,30 - задовільна стійкість, 2,31-2,70 - низька стійкість, 2,71-3,00 бала - дуже низька стійкість до фізичного навантаження.

Для оцінювання соматичного здоров'я визначали довжину та вагу тіла, життєву ємність легенів, силу м'язів кисті, систолічний артеріальний тиск, частоту серцевих скорочень у стані спокою та час іiї відновлення після функціональної проби (20 присідань за 30 c). При цьому оцінювання рівня соматичного здоров'я здійснюється за такою градацією: низький, нижче середнього, середній, вище середнього та високий.

Для визначення морфофункціональних особливостей еритроцитів у всіх студентів забирали кров двічі: натщесерце та на першій - третій хвилині відновного періоду після виконання рекомендованого фізичного навантаження. Для дослідження структурних змін еритроцитів брали першу краплю капілярної крові з нігтьової фаланги четвертого пальця кисті, другу крап- 
лю використовували для визначення рівня глюкози глюкометром «Accu-Chek Active» (Німеччина).

Концентрацію гемоглобіну досліджували стандартним ціанметгемоглобіновим методом, кількість еритроцитів - уніфікованим методом підрахунку в камері Горяєва, гематокрит визначали мікрометодом із використанням стандартних гепаринізованих капілярів. Додатково розраховували морфофункціональні характеристики еритроцитів: MCV кондуктометричним (імпедансним) методом; МСН, МСНC - розрахунковими методами (автоматичний аналізатор). За стандартними методиками досліджували резистентність еритроцитів до гемолітичних дій (кислотної, осмотичної). Кислотну резистентність визначали на основі різної стійкості еритроцитів до соляної кислоти. Визначали так показники: час початку гемолізу $\left(\mathrm{t}_{0}\right)$; час закінчення гемолізу $\left(\mathrm{t}_{100}\right)$; тривалість гемолізу $\left(\mathrm{t}_{\mathrm{r}}\right)$ за формулою: $\mathrm{t}_{\mathrm{r}}=\mathrm{t}_{100}-\mathrm{t}_{0}$, а також час $50 \%$ гемолізу $\left(\mathrm{t}_{50}\right)$. Осмотичну резистентність визначали за концентрацією гіпотонічного розчину натрію хлориду.

В еритроцитах досліджували: концентрацію відновленого глутатіону (Hernayanti et al., 2015), активність глюкозо-6-фосфатдегідрогенази (КФ 1.1.1.49) (Karaseva and Metelitza, 2006) i глутатіонредуктази (КФ 1.6.4.2) (Chen and Nam, 2016).

Аналіз мазків виконано за допомогою мікроскопа Leica CME $з$ подальшим переведенням зображення у цифрову форму (відеокамера Sony ExwaveHad SSC-DC58AP). Для більш чіткого виявлення та збільшення якості вимірів, еритроцити попередньо фарбували за оригінальною методикою (Karle, 2009). Вимірювали максимальний та мінімальний діаметр еритроцитів, довжину їх окружності, визначали відсоткове співвідношення їх морфотипів до та після стандартного фізичного навантаження. Мазки крові протягом 10 хв фіксували у парах формаліну, обробляли н-бутанолом протягом 2 хв, потім занурювали у 0,01\% розчин бромфенолового синього у суміші етанол-діоксан-оцтова кислота (5: $4: 1)$ на 10 хв і після повторного промивання у н-бутанолі висушували протягом 2 хв для перегляду під мікроскопом. Підрахунок здійснювали на 500 клітин. Мікрофотографування проводили за допомогою цифрової фотокамери «Olympus Camedia C-480 ZOOM» (Olympus Corp., Японія). Зображення аналізували із застосуванням пакетів програм NIHimage (Macintosh) та ScionImage (PC).

Морфологічні дослідження проводили у світлооптичному мікроскопі МС 300 (ТХР) та сканувальному електронному мікроскопі JEOL-25M-T220A (Японія) за загальноприйнятими методиками з визначенням мікроелементного складу еритроцитів.

Статистичну обробку результатів досліджень здійснювали за допомогою програмного пакета GrafPad Prism 4.0 (GrafPad Sowtware Inc., США). Застосовували непараметричні методи дослідження (критерій Уїлкоксона, Манна - Уїтні). Вибіркові параметри, наведені далі у таблицях і тексті, мають такі позначення: $x$ - вибіркове середнє, SE - стандартна помилка середнього. Виявлені зміни вважали статистично значимими тоді, коли отриманий рівень відповідав $\mathrm{P}<0,05$.

\section{Результати}

Аналіз анкетування показав, що 88\% студентів експериментальної групи не справляються 3 навчальним навантаженням внаслідок інтенсивних занять спортом, насиченим тренувальним графіком і участю у змагальный діяльності. Також 72\% студентів цієї групи вказують на хронічну втому.

Ці дані добре узгоджуються 3 показниками адаптаційного потенціалу, який виявився у студентів-спортсменів на 52\% нижчим, ніж у нетренованих студентів ( $<<0,05)$. Отримані дані про адаптаційний потенціал вказують на чітку різницю у структурі фізичної працездатності студентів із різним режимом навчання та фізичного навантаження наприкінці навчального року. Якщо у нетренованих студентів до зони задовільної працездатності належать 45\% від їх загальної кількості, а до категорії низької - 45\%, то у студентів-спортсменів 25\% можна віднести в зони задовільної, а 46\% і 29\% відповідно до зони з низькою та дуже низькою працездатністю. У зоні високої адаптації до фізичного навантаження в кінці навчального року не виявлено жодного з усіх обстежених студентів.

У нетренованих студентів у кінці навчального року середній і вище за середній рівні соматичного здоров'я виявлено у 1,5 раза частіше, ніж у студентів-спортсменів, що також вказує на негативний вплив на їх організм режиму дня 3 підвищеним рівнем фізичного (тренувального) навантаження. В усіх студентів до тестування 3 фізичним навантаженням вміст еритроцитів, гемоглобіну та показники гематокриту крові перебувають у межах фізіологічної норми, за помірно підвищеної кількості ретикулоцитів в експериментальній групі (табл. 1).

\section{Таблиця 1}

Зміни показників еритроцитів нетренованих студентів і студентів, які тренують витривалість, до та після одноразового фізичного наванаження $(\mathrm{x} \pm \mathrm{SE})$

\begin{tabular}{|c|c|c|c|c|}
\hline \multirow{2}{*}{ Показники } & \multicolumn{2}{|c|}{$\begin{array}{c}\text { Контрольна группа }(\mathrm{n}=25), \\
\text { нетреновані студенти }\end{array}$} & \multicolumn{2}{|c|}{$\begin{array}{c}\text { Експериментальна группа }(\mathrm{n}=25) \\
\text { студенти-спортсмени }\end{array}$} \\
\hline & $\begin{array}{c}\text { до фізичного } \\
\text { навантаження }\end{array}$ & $\begin{array}{c}\text { після фізичного } \\
\text { навантаження }\end{array}$ & $\begin{array}{c}\text { до фізичного } \\
\text { навантаження }\end{array}$ & $\begin{array}{c}\text { після фізичного } \\
\text { навантаження }\end{array}$ \\
\hline Еритроцити, $10^{12} /$ л & $4,55 \pm 0,19$ & $4,88 \pm 0,22$ & $4,70 \pm 0,24$ & $4,39 \pm 0,18^{* \#}$ \\
\hline Гемоглобін, г/л & $144,90 \pm 2,62$ & $148,40 \pm 2,54^{\#}$ & $146,11 \pm 4,15$ & $146,43 \pm 2,91$ \\
\hline Гематокрит,\% & $44,20 \pm 2,82$ & $46,70 \pm 1,89^{\#}$ & $44,90 \pm 3,93$ & $46,80 \pm 2,44^{\#}$ \\
\hline Середній об'єм еритроцита, фл & $89,89 \pm 5,02$ & $91,95 \pm 4,83^{\#}$ & $88,76 \pm 2,49$ & $92,67 \pm 2,95^{* \#}$ \\
\hline Коефіцієнт варіації об’єму еритроцита,\% & $14,20 \pm 1,54$ & $16,40 \pm 1,71^{\#}$ & $13,70 \pm 2,00^{*}$ & $15,40 \pm 1,35^{* \#}$ \\
\hline Ретикулоцити,\% & $1,02 \pm 0,32^{*}$ & $1,02 \pm 0,32^{*}$ & $1,34 \pm 0,39$ & $1,76 \pm 0,39^{\#}$ \\
\hline
\end{tabular}

Примітки: ${ }^{*}-\mathrm{P}<0,05$ порівняно $з$ контрольною групою, ${ }^{\#}-\mathrm{P}<0,05$ порівняно з попереднім терміном спостереження.

Під час морфологічного дослідження практично в усіх обстежених студентів констатували підвищення вмісту еритроцитів зі зміненою поверхневою цитоархітектонікою. За фізіологічної норми допускають уміст змінених клітин не більше $8 \%$, а вміст незворотно змінених еритроцитів не має перевищувати 1\% їх загальної кількості. У периферійній крові студентів-спортсменів разом із нормоцитами 3 високою гемоглобінізацією реєстрували субпопуляції макроцитарних і мікроцитарних клітин iз низьким рівнем гемоглобіну (рис. 1).

Для окремих студентів характерна присутність у периферійній крові зворотно та незворотно змінених форм еритроцитів, кількість яких перевищувала рекомендовану межу фізіоло- гічної норми. Слід зауважити, що поява цих форм еритроцитів має суто індивідуальний характер і немає статистично вірогідного групового характеру. Спостерігалися ехіноцити з дрібною узурацією зовнішньої мембрани (рис. 2), а в окремих студентів мали місце аканто-, стомато-, (рис. 3) та ехіноцити (рис. 4).

Після дозованого фізичного навантаження у 43\% студентів експериментальної групи спостерігали збільшення кількості еритроцитів, тоді як у 57\% студентів їх кількість знижувалася. При цьому статистично вірогідні зміни вмісту гемоглобіну та показників гематокриту не спостерігається, тоді як мікроскопія мазків крові у студентів зі зниженою кількістю еритроцитів вказує на їх лізис (рис. 5). 


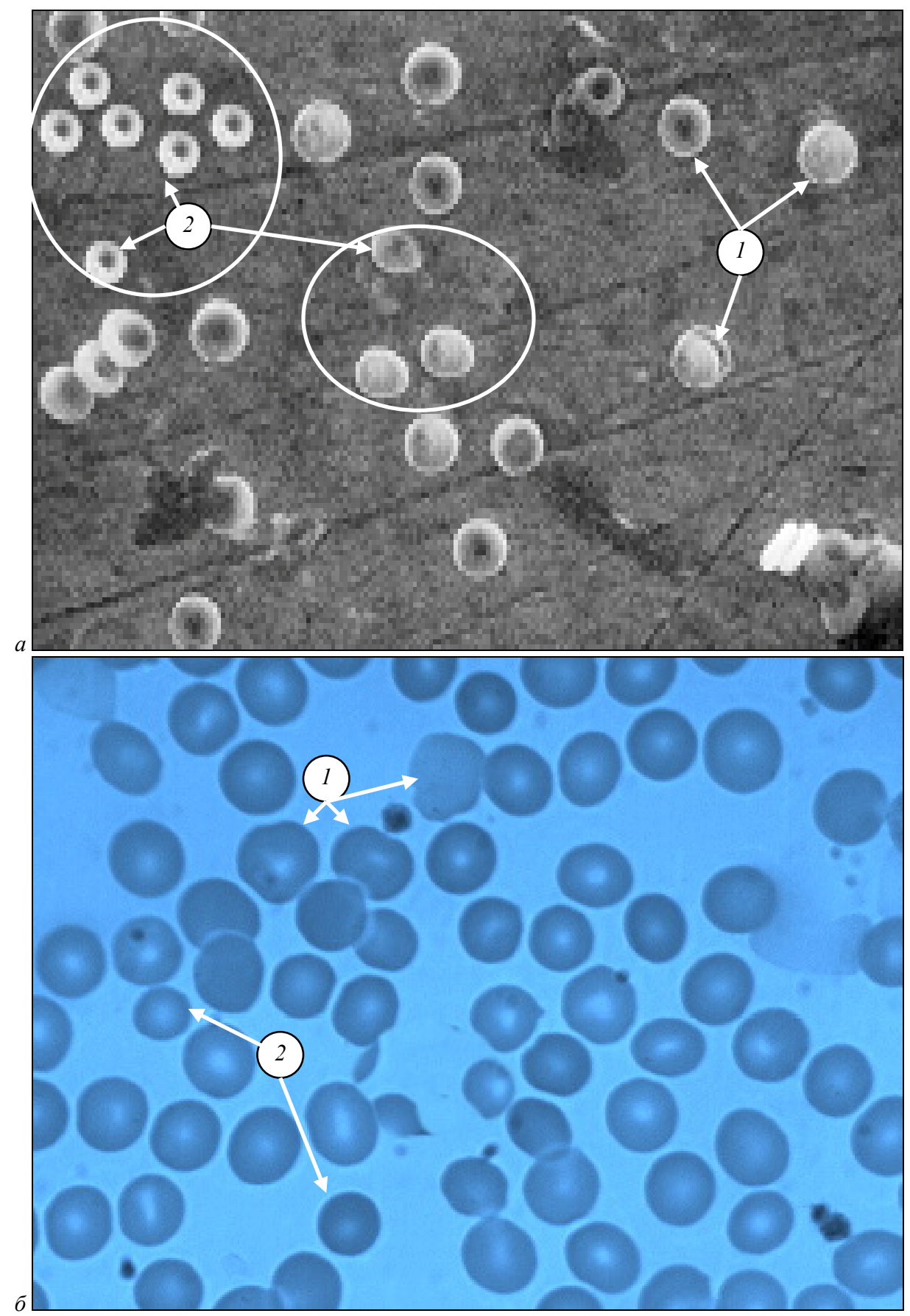

Рис. 1. Нормоцити, субпопуляція макро- (1) та мікроцитарних (2) еритроцитів у крові студентів-спортсменів після дозованого велоергометричного фізичного навантаження: $a$ - сканувальна електронна мікроскопія, $\sigma$ - забарвлення за Романовським; $a-{ }^{\mathrm{x}} 1350, \sigma-{ }^{\mathrm{x}} 1000$

У фізіологічних умовах еритроцити, які циркулюють у периферійній крові, відрізняються один від одного розмірами, структурою, метаболізмом та іншими фізико-хімічними якостями, що зумовлені їх віковими особливостями. Для характеристики вікової різноякісності еритроцитів запропоновано визначати їх стійкість до біологічних, термічних, хімічних факторів середовища. В усіх студентів виявлено знижену осмотичну стійкість еритро- цитів, виразність якої залежала від форми клітин. Зниження осмотичної стійкості, збільшення на еритрограмі групи низькостійких клітин корелює з переважанням еритроцитів сферичної форми.

У студентів поряд зі зниженням кількості еритроцитів після фізичного навантаження знижується активність як глюкозо6-фосфатдегідрогенази (на 29,5\%, Р < 0,05), так і глутатіонредуктази $(23,2 \%, \mathrm{P}<0,05)$ (табл. 2).

\section{Таблиця 2}

Біохімічні показники еритроцитів нетренованих студентів і студентів, які тренують витривалість $(\mathrm{x} \pm \mathrm{SE})$

\begin{tabular}{|c|c|c|c|}
\hline Показники & Фізіологічна норма & Контрольна група $(\mathrm{n}=25)$ & Експериментальна группа (n=25) \\
\hline Вміст відновленого глутатіону, мкмоль/г гемоглобіну & $5,18-6,38$ & $5,95 \pm 0,44$ & $4,95 \pm 0,27^{*}$ \\
\hline Активність глюкозо-6-фосфатдегідрогенази, мкмоль/(хв.г гемоглобіну) & $4,93-6,17$ & $5,15 \pm 0,39$ & $4,35 \pm 0,67^{*}$ \\
\hline Активність глутатіонредуктази, мкмоль/(хв.г гемоглобіну) & $185,0-233,0$ & $198,0 \pm 10,2$ & $179,5 \pm 6,7^{*}$ \\
\hline
\end{tabular}

Примітка: * - $\mathrm{P}<0,05$ порівняно з контрольною групою. 


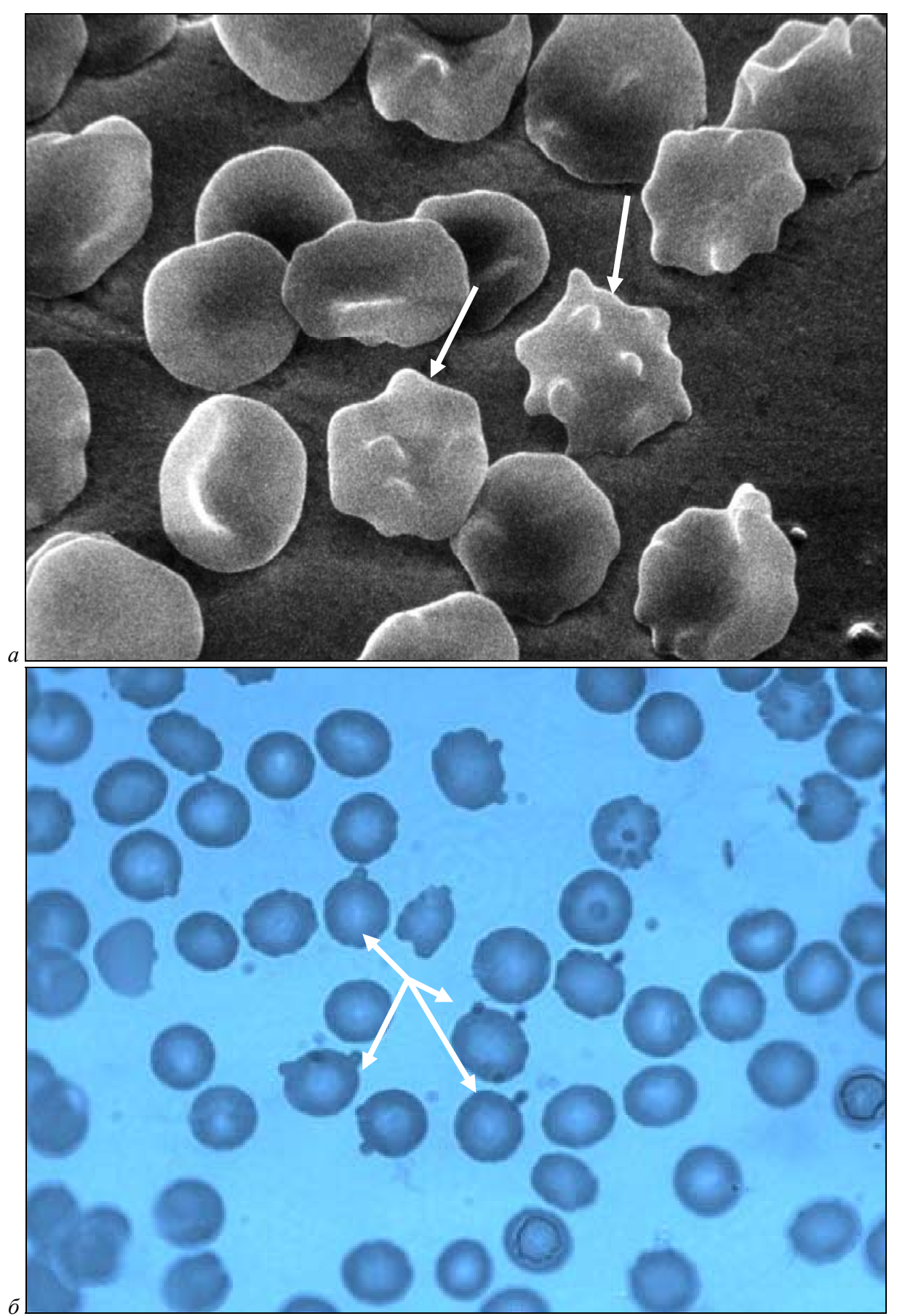

Рис. 2. Клітини ехіноцити (показані стрілками) в крові студентів-спортсменів:

$a$ - сканувальна електронна мікроскопія, $\sigma$ - забарвлення за Романовським; $a-{ }^{\mathrm{x}} 5000, \sigma-{ }^{\mathrm{x}} 1350$

При цьому у контрольній групі вміст відновленого глутатіону залишається в межах діапазону показників фізіологічної норми, тоді як у студентів експериментальної групи його концентрація зменшується на 22,4\% (P <0,05).

\section{Обговорення}

Проведені дослідження стосовно адапатційного потенціалу студентів показали, що у кінці навчального року студентиспортсмени мають низький рівень функціональних резервів організму, що вимагає пильної уваги вчених різних спеціалізацій до їх психо-фізичного стану. При цьому виявлений нами чіткий взаємозв'язок між режимом навчання студентів із різним рівнем фізичного навантаження протягом дня та величиною адапатційного потенціалу вказує на те, що запропоновану градацію його величини можна використовувати як кри- терій для визначення об'єму навчально-тренувальних навантажень протягом усього навчального року. Це узгоджується 3 аналогічними критеріями, встановленими іншими авторами (Ignat'eva and Kubasov, 2014).

Фізичне навантаження різного рівня інтенсивності відіграє велику роль у формуванні загальної витривалості організму, яка виявляється у різного роду діяльності та у повсякденному житті людей (Lambert, 2016). Вона відображає загальний piвень працездатності організму людини. Будучи багатофункціональною властивістю людського організму, витривалість інтегрує в собі велику кількість процесів, що відбуваються на різних рівнях: від клітинного та до цілісного організму (Bergamini et al., 2004). Як показують результати сучасних наукових досліджень, у переважній більшості випадків провідна роль у дослідженнях витривалості належить встановленню факторів, які сприяють активізації енергетичного обміну та вегетативних 
систем його забезпечення - серцево-судинної та дихальної, а також центральної нервової системи. При цьому залишаються поза увагою дослідження клітинних реакцій за фізичного навантаження у процесі тренувань, пов'язаних із підвищенням загальної витривалості організму студентів (Koumantakis et al., 2005; Kang, 2016). Еритроцити в даному випадку служать зручним об'єктом для такого роду досліджень, оскільки вони мають участь у процесах, пов'язаних із підтриманням гомеостазу на рівні цілого організму (Jensen, 2009; Mairbäurl, 2013; Mikhaylova, 2013). Ці клітини крім властивої для них специфічної газотраспортної функції мають здатність брати участь у регуляції кислотно-лужного стану, водно-електролітного балансу, мікрореологічного статусу крові, в імунних реакціях, зв’язуванні та перенесенні амінокислот і ліпідів, що являє безпосередній інтерес для розвитку загальної витривалості організму (Shephard and Åstrand, 2000; Nemytov, 2007; Valbones et al., 2009; Tan et al., 2010; Zhu, 2015).

Під час фізичного навантаження відбувається статистично вірогідне збільшення гематокриту на 5,0\%, а рівня гемоглобіну на 2,7\%. Однак на загальному фоні збільшення числа еритроцитів у силу розвитку гемоконцентрації, в окремих студентів контрольної групи фізичне навантаження викликає зменшення кількості еритроцитів. Таке явище може бути викликане деструктивним впливом на еритроцити посиленням гемодинаміки, підвищенням температури, ацидозом під час фізичного навантаження тощо.

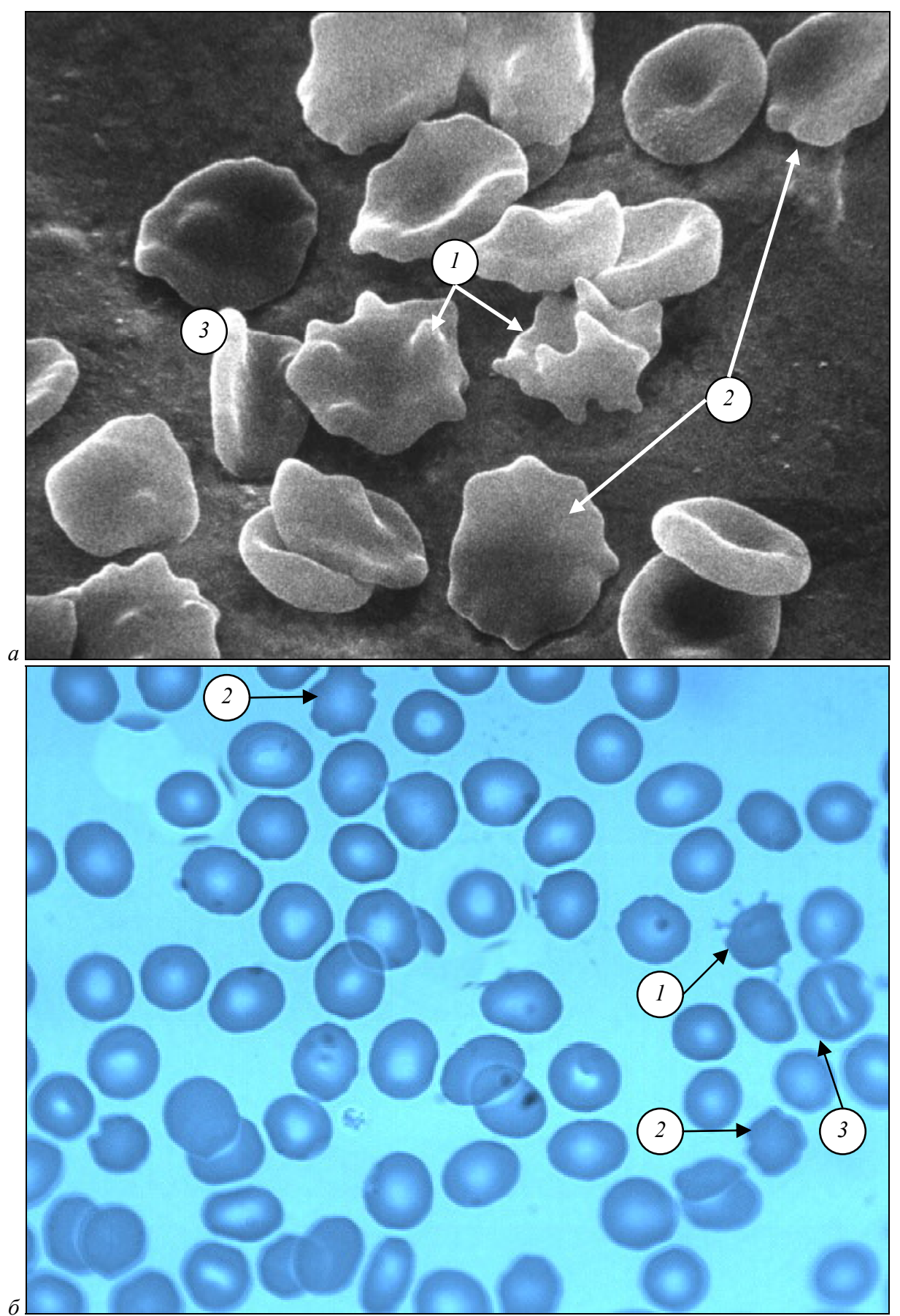

Рис. 3. Атипові форми еритроцитів крові студентів-спортсменів: ехіноцити (1), акантоцити (2) та стоматоцити (3); $a$ - сканувальна електронна мікроскопія, $\sigma$ - забарвлення за Романовським; $a-{ }^{\mathrm{x}} 5000, \sigma-{ }^{\mathrm{x}} 1350$

Одноразове фізичне навантаження викликає збільшення кількості великих еритроцитів на $3,0 \%(\mathrm{P}<0,05)$. Кількість і об'єм циркулюючих еритроцитів визначає реологічні власти- вості крові. Зміна цих показників за фізичного навантаження може істотно впливати на киснево-транспортну функцію крові і здатне спричинювати негативні явища в системі мікроцир- 
куляції, тим самим зменшуючи адаптаційний потенціал організму студентів (Valbonesi et al., 2009). Посилення агрегації еритроцитів (вміст агрегатів збільшився на 15,6\%) і підвищення коефіцієнта їх деформованості (на 17,9\%), що спостерігаються внаслідок м'язової роботи, викликає підвищення в'язкості циркулюючої крові. Такі зміни показників еритроцитів несприятливі для реалізації кисневотранспортної функції крові та свідчать про недостатню адаптацію нетренованих студентів до фізичного навантаження (Lambert, 2016). Дефіцит в еритроцитах відновленого глутатіону, знижена активність глюкозо-6- фосфодегідрогенази та глутатіонредуктази за впливу окисних агентів зумовлює зниження вмісту глутатіондисульфіду. У разі виснаження процесів регенерації глутатіону сповільнюються або припиняються внутрішньоклітинні окисно-відновні процеси, настає «хімічна», а, отже, і біологічна смерть еритроцитів (Holcik, 2001). Вони або фагоцитуються клітинами моноцитарно-фагоцитарної системи (під час фізіологічного старіння чи внаслідок апоптозу), або піддаються внутрішньосудинному розпаду за впливу окисних агентів (Abdelha and Abdelmotta, 2010).

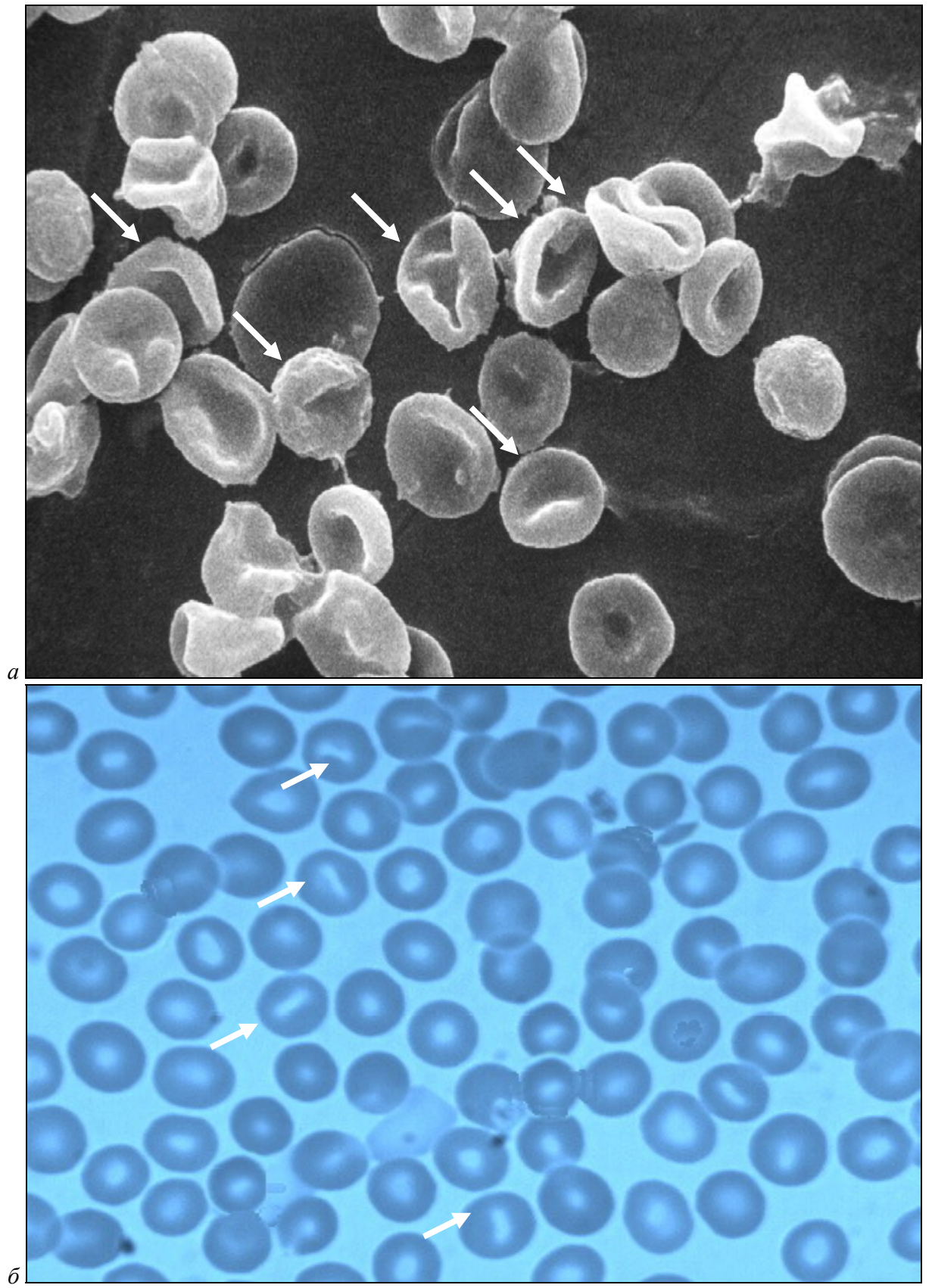

Рис. 4. Стоматоцити (показані стрілками) в крові студентів-спортсменів:

$a$ - сканувальна електронна мікроскопія, $\sigma$ - забарвлення за Романовським; $a-{ }^{\mathrm{x}} 3000, \sigma-{ }^{\mathrm{x}} 1350$

Під час дослідження ми встановили, що у 57\% студентівспортсменів за впливу дозованого фізичного навантаження виникають негативні морфологічні зміни еритроцитів, що зумовлено дисметаболічними порушеннями. Основу цих змін, ймовірно, складає невідповідність функціональних можливостей біосистем організму до поєднаного негативного впливу підвищеного об'єму навчального та високого рівня інтенсивності фізичного навантаження (Brock et al., 2009; Chen and Nam, 2016).
За таких умов виникають порушення структурної цілісності еритроцитів, що, у свою чергу, сприяє їх внутрішньосудинному лізису та може спричинити розвиток анемії (Matarrese, 2005). Наявність цих змін, як правило, негативно впливає на рівень соматичного здоров'я, спортивну результативність i успішність студентів. Це вимагає відповідної корекції навчального та тренувального процесу, а також ліквідації негативних наслідків, розроблення та своєчасного застосування адекват- 
них заходів, спрямованих на усунення розвитку можливих патологічних змін в організмі студентів. У сучасних дослідженнях системи крові набула поширення кислотна еритрограма або тест розподілу еритроцитів відносно часової стійкості до дії кислоти (Abdelha and Abdelmotta, 2010). Результати обстежень за цією методикою вказують, що у студентів із пониженою кількістю еритроцитів після фізичного навантаження спостерігається зниження стійкості мембрани еритроцитів до кислотного гемолізу, що проявляється зміною часу гемолізу та його максимуму. Окремі автори вважають, що лізис еритроцитів під час пониження $\mathrm{pH}$ середовища зумовлений денатурацією та подальшою агрегацією мембранних білків (Mohanty et al., 2014) внаслідок олігомеризації білків цитоскелета. Такі явища найбільш виражені у зрілих і старих еритроцитах (Ratcliffe and Bishop, 2014).
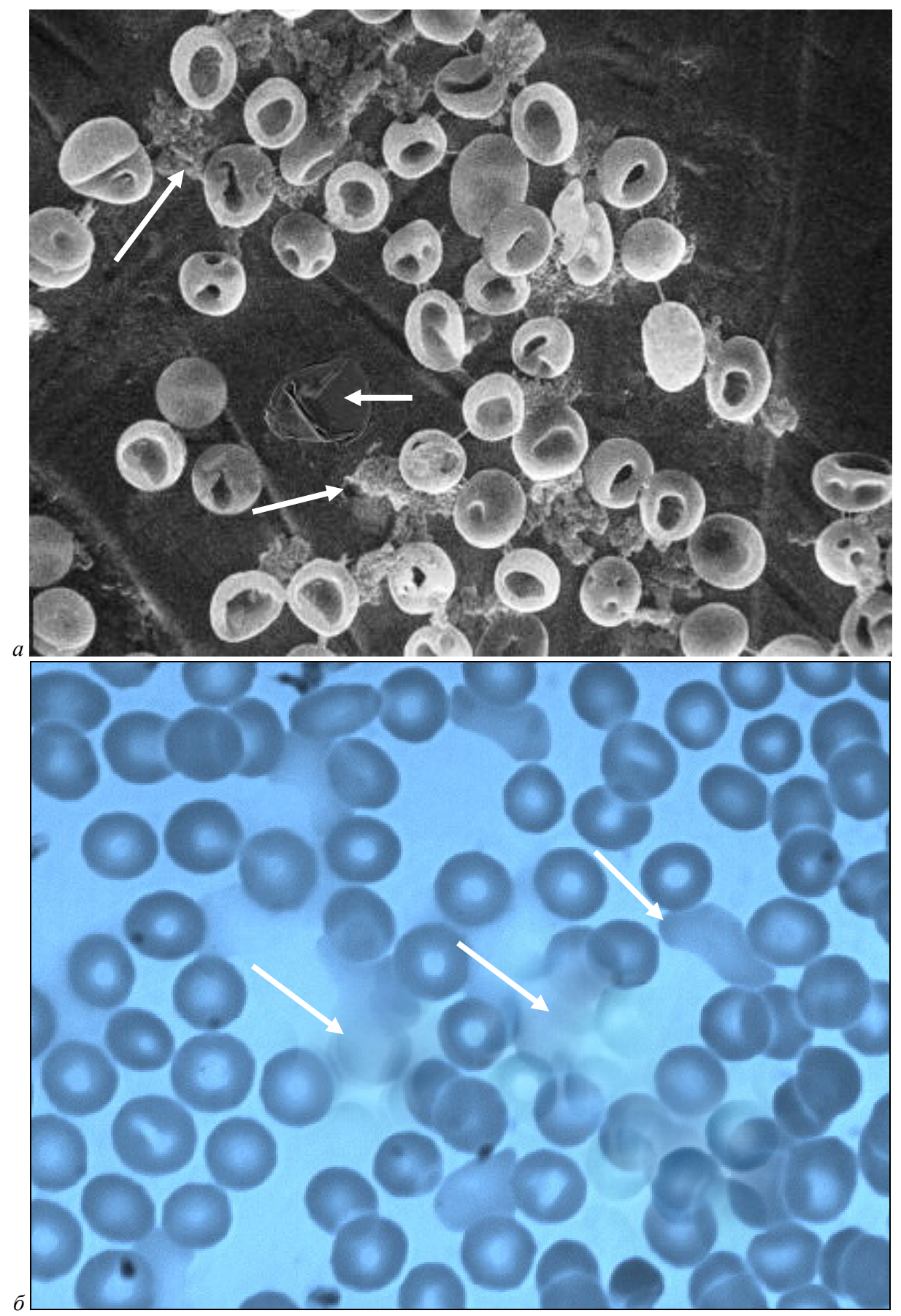

Рис. 5. Специфічні літичні форми еритроцитів (показані стрілками) в мазку крові студентів-спортсменів: $a$ - сканувальна електронна мікроскопія, $\sigma$ - забарвлення за Романовським; $a$ - ${ }^{\mathrm{x}} 1500, \sigma$ - ${ }^{\mathrm{x}} 1350$

Домінування у крові студентів вмісту еритроцитів зі зміненим поверхневим мікрорельєфом, зниження стійкості клітинної мембрани за кислотного гемолізу, як і реєстрація в окремих студентів після рекомендованого фізичного навантаження лізисних форм еритроцитів, може бути зумовлене цілою низкою причин, що мають у своїй основі розвиток дискоординації метаболічних процесів і супроводжуються ушкодженнями мембрани. Поява змішаних структурних змін в еритроцитах вказує на високий ризик внутрішньосудинного гемолізу, особливо се- ред студентів зі зворотно зміненими формами, та розвитку патологічного стану, що у спортивній медицині отримав назву «анемія навантаження, або змагальна анемія» (Mairbäurl, 2013).

Зважаючи на це, ми дослідили активність окремих ферментів еритроцитів, які беруть участь у метаболізмі: глюкозо-6фосфатдегідрогенази та глутатіонредуктази, які забезпечують збереження мембрани еритроцитів за їх окиснення за дії різних факторів. Ці ферменти посідають ключове місце у внутрішньоеритроцитарному метаболізмі, зокрема, беруть участь 
у пентозофосфатному циклі перетворення глюкози та глутатіоновому циклі (Chen et al., 2010; Hernayanti et al., 2015). Близько 90\% глюкози, що засвоюється в еритроциті, перетворюється у процесі гліколізу на лактат і приблизно $10 \%$ окиснюється через утворення глюкозо-6-фосфату у 6-фосфоглюконат. Вказану реакцію каталізує глюкозо-6-фосфат. Саме ця реакція в основному забезпечує еритроцит необхідною кількістю відновленого нікотинамідаденін-динуклеотидфосфату, найважливішого донатора водню, що використовується для відновлення глутатіону (Karaseva and Metelitza, 2006). Відновлення глутатіону до глутатіондисульфіду відбувається за безпосередньої участі глутатіонредуктази, основна функція якої полягає у захисті сульфгідрильних груп білків, зберігаючи їх у відновленому стані. Швидка регенерація глутатіону оберігає гемоглобін від окиснювальної денатурації.

Лінійні розміри еритроцитів упродовж усього періоду тренувального збору характеризуються малими, але системними зрушеннями. Зокрема, максимальні розміри еритроцитів розрізняються тільки у вигляді тенденцій до збільшення діаметрів. Однак по коротких осях спостерігаються значніші $(\mathrm{P}<0,05)$ відмінності. Центральні ямки дисків поглиблюються, але при цьому на 50-75 нм зменшується товщина дисків, що зумовлено зменшенням товщини білково-глобулярного шару мембрани еритроцитів (Jensen, 2009; Karle, 2009; Bianchini and Wright, 2013). Це має адаптивне значення, оскільки розширює пластичні можливості еритроцитів під час проходження через капілярний сегмент гемомікроциркуляторного русла. Отримані нами дані вказують на досить малі відхилення кожного 3 параметрів (у межах 5-7\%), але вони накопичуються та набувають системного характеру. Це робить дані зрушення функціонально значимими в кінці навчального року.

На відміну від контрольної групи, де гістограма розподілу еритроцитів має вигляд нормального розподілу, тоді як в експериментальній групі гістограма розподілу еритроцитів за розміром асиметрична та мультиполярна за рахунок збільшення лівого крила, тобто внаслідок зростання кількості варіюючих класів клітин малого розміру. Порівняльний аналіз показує, що у контрольній групі об'єм розмірних класів у лівому крилі складає тільки $20 \%$, тоді як в експериментальній групі близько 70\%. Збільшення кількості еритроцитів лівого крила гістограми супроводжується вірогідним $(\mathrm{P}<0,05)$ зменшенням значень медіани та моди.

Вказані особливості гістограми означають, що у відповідь на дію фізичного навантаження реагують, перш за все, еритроцити малих розмірів, що характерно для короткотривалих, швидкоплинних реакцій, які, очевидно, відбуваються внаслідок викиду клітин «першого ешелону стрес-реакції» з резервного пулу загального кровотоку (Holcik, 2001; Mairbäurl, 2013).

Розподіл еритроцитів у студентів експериментальної групи стає більш екстремальним: збільшується кількість інтервалів, об'єми окремих класів варіюють унаслідок різких «стрибків», а досягнення значень центральних параметрів відбувається хвилеподібно (у контролі по монотонно висхідному тренду). Хвилеподібна форма гістограми, мабуть, відображає нестабільно-коливальний стан еритроцитів у періоді активного тренування організму (Shephard and Åstrand, 2000; Lambert, 2016). Це підтверджується зміною електролітного складу еритроцитів, перш за все натрію та калію, оскільки відомо, що їх співвідношення дозволяє опосередковано оцінити стан клітинного метаболізму в цілому організмі (Hernayanti et al., 2015). Тому знання загальних закономірностей розподілу електролітів в організмі, зокрема, калію та натрію, а також взаємостосунків цього розподілу з концентрацією та пересуванням іонів інших металів дозволяє скласти загальне уявлення про те, що відбувається всередині кожної клітини в організмі (Jensen, 2009).

Безпосередня небезпека загальної та, головним чином, клітинної гіпокаліємії полягає в тому, що, перш за все виникає гіпорефлексія та страждає скоротлива функція м'язів, зокрема міокард і гладка мускулатура кишечника. За внутрішньоклі- тинної гіпокаліємії можливий розвиток паралічів скелетної мускулатури, паралітичної кишкової непрохідності, серцевих аритмій (Maroulis et al., 2000; Streeten et al., 2008; Chang and Bo, 2015), а також підвищеної чутливості до допінг-препаратів, які так часто присутні в різних тренувальних схемах у спортивній підготовці студентів (Takahashi and Tatsugi, 2013).

Оцінка більш інформативного показника, так званої трансмінералізації еритроцитів і трансмембранного потенціалу по калію дає можливість судити про втрати клітинної маси еритроцитів. Зниження трансмембранного потенціалу по калію нижче 20 ммоль/л свідчить про загальний дефіцит калію в організмі людини, а зменшення трансмінералізації внаслідок зниження показників концентрації калію та збільшення вмісту натрію дозволяє припускати наявність подібних порушень і в інших клітинних структурах.

За дії екстремальних чинників система переходить у детермінований стан, хаотичність флуктуацій зменшується, коливання набувають регулярного, впорядкованого характеру. Статистично цей ефект виявляється у вигляді зменшення показників дисперсії та ексцесу. Еритроцит немовби «стискається» та переходить до більш мономорфного унімодального стану. Зменшуються числові значення ширини інтервалів, що вказує на вкорочення сумарної довжини хвилі флуктуюючих коливань. Якщо інтерполювати ці співвідношення на індивідуальні клітини, можна припустити, що за впливу фізичного навантаження в організмі студентів із низьким рівнем тренованості чи у стані психофізичного перенавантаження збуджуються флікерні (шумові) коливання еритроцитів, які ведуть до появи мікро- та макродискоцитів (Hernayanti et al., 2015).

При цьому самі клітини піддаються пружній деформації, а коливання, виходячи 3 форми розмірних гістограм, по амплітуді та частоті стають вище початкових. Збільшення частоти осцилюючих коливань неминуче викликає розбалансування стабільного стану клітинної мембрани, а це, у свою чергу, посилить плавлення ліпідів та підвищить текучість мембран. Морфологічно це виявляється активною конформацією еритроцитів $\mathrm{i}$ розширенням мембранних пор. Вони стискаються або витягуються, що відповідає вищим значенням коефіцієнта варіації показників індексу форми. Зміни фізичного стану мембранних ліпідів супроводжуються зменшенням показників шорсткості та питомої площі поверхні мембран.

Це означає, що в мембранах еритроцитів збільшується поверхневий натяг i, відповідно, зменшується поверхнева енергія. Збільшенню поверхневого натягу сприяє також ущільнення мембрани еритроцитів, що спостерігається у вигляді збільшення вагових індексів натрію, кальцію, магнію та хлору, але знижується концентрація калію, схильного виходити з клітини за дії найрізноманітніших механічних або біохімічних перетворень (Maroulis et al., 2000; Streeten et al., 2008; Chang and Bo, 2015). Внаслідок дії сил поверхневого натягу мембрани розправляються, кількість вогнищ, що концентрують напруження зменшується, а мембрани стають міцнішими на розрив. Одночасно у поверхневих шарах стінки еритроцитів з'являються вогнища ущільнень. Морфологічно ці вогнища мають вигляд дегранульованих ділянок, які виступають на 50-80 нм над поверхнею. За даними вимірювань, знятих із цих ділянок, показники шорсткості та адгезивність істотно зменшуються відносно решти поверхні дискоцитів. Це означає, що дані ділянки більш гідрофобні, тобто мають меншу здатність до змочування. У нормі питома площа таких ділянок не перевищує 5\%, i їх поява, імовірно, зумовлена підсиханням зразків. Проте в експериментальній групі площа вогнищ ущільнення збільшується практично удвічі та коливається в межах 10\%. Механізми формування подібних ділянок невідомі, але одним із них вважають стресс-зумовлене посилення золь-гель-переходів у ліпопротеїнових комплексах цитоплазматичних мембран. На фоні посилення коливальних рухів еритроцитів і збільшення сил поверхневого натягу, безумовно, посиляться також процеси утворення капілярних хвиль у трансмембранний рідині. 
Швидкість руху хвиль у міру зростання поверхневого натягу збільшується, а довжина, у зв'язку зі стоншенням дисків зменшується (Holcik, 2001). Вказані фундаментальні співвідношення створюють структурні та фізико-механічні передумови для високочастотного зсуву осцилюючих коливань внутрішньоклітинної рідини та мембранних структур еритроцитів (Karle, 2009). Внаслідок нерівномірного розтягування мембрани з'являються вогнища ущільнення з гідрофобною поверхнею та западини з гідрофільними дном і краями. Це збільшує неоднорідність швидкостей і структури гідродинамічних потоків: у розширених порах із гладкими стінками потоки ламінізуються та прискорюються, а в заглибленнях, навпаки, - вони сповільнюються та піддаються турбулентним закручуванням. У результаті цього на певних ділянках мембрани еритроцитів різко зростає тиск, що викликає вдавлювання країв, утворення різноманітних виростків, застій високоадгезивної плазматичної рідини та накопичення частинок «липкого» детриту.

Інтенсивність трансмембранного обміну та, зокрема, швидкість гідродинамічних потоків великою мірою визначаються структурою та формою пор (Bergamini et al., 2004; Abdelha and Abdelmotta, 2010; Mohanty et al., 2014). У мембранах еритроцитів студентів-спортсменів діаметр входу, глибина та відносний об'єм пор істотно вищі за контрольні значення тому, що мембрани стають більш пористими, i, відповідно, більш проникливими. Враховуючи багатократне перевищення відносного об' $€$ му, відбувається це стрибкоподібно. I не тільки за рахунок розширення, а і шляхом утворення пор de novo. Розширені пори мають підвищені краї, виконані різнокаліберними зернами із субгранулярною організацією. Багато пор мають лійкоподібну форму з подовженим загостреним «горлом». У нормі лійкоподібні пори зустрічаються рідше, а їх діаметр не перевищує 150 нм. В еритроцитах студентів-спортсменів лійкоподібні пори більші за розмірами (діаметром до 250 нм), дно покрите тонким шаром безформенної «в'язкої» маси та невпорядкованими гранулами.

Простір між гранулами розширений, створює масштабну мережу ультратонких каналів, що спостерігаються на мікрофотографіях за великих збільшень сканувального електронного мікроскопа. Горловина пор глибоко проникає у багатошарові стінки еритроцитів.

Внаслідок різноспрямованої дії деформівних сил мембрани в еритроцитах розправляються нерівномірно: 3'являються обширні (діаметром до 300 нм), але неглибокі (15-25 нм) западини. «Береги» западин характеризуються значними перепадами висот, порізані закрутами та схилами. У місцях підйому «береги» немовби вивертаються та можуть піднятися до 100 нм. У функціональному відношенні це означає орієнтацію еритроцитів на переважне виведення речовини, а у патоморфологічному розумінні це розцінюється як підготовка до піроптозу різновиду апоптозу, у ході якого дегенеративно змінені клітини викидають (виплескують) цитоплазматичний матеріал (Holcik, 2001; Karle, 2009). Закрути (меандри) - петлеподібні прогинання дна на ділянці до 50-100 нм, що розчленовують стінки западин. Поява подібних структур свідчить про уповільнення потоків трансмембранної рідини. Схили в основному опуклі, а їх мікрорельєф ускладнюється дво-триярусними терасами, сходинки яких оголяють пластинчасту структуру стінок еритроцитів. Сканування дна западин у режимі вторинних електронів дозволяє деталізувати тонку текстуру поверхні, виявляються наноканали та частинки детриту різного ступеня дисперсності. Наноканали утворюють густу розгалужену сітку, а детрит відкладається переважно у «прибережних» ділянках у вигляді поліморфних аглютинатів.

Поверхня западин, особливо на дні, відрізняється високою адгезивністю, що свідчить про накопичення в'язкої маси. Вищеперераховані морфологічні особливості ускладнюють текстуру поверхні еритроцитарних дисків. Це зумовлює неоднорідність швидкості та структури внутрішньо- та трансмембранних гідродинамічних потоків. Під час проходження рідини через розширені пори з відносно гладким рельєфом стінок швидкість потоків збільшується і вони ламінізуюються. У дрібних западинах із розгалуженими краями швидкість гідродинамічних потоків сповільнюється і вони починають закруглятись. За зменшення кінетичної енергії (швидкості) гідродинамічних потоків тиск (i, відповідно, тертя, що створюється біля стінки та дна западини), збільшується. Циркулююча трансмембранна рідина починає застоюватися, «замулюватися», перетворюється на в'язкий флюїд, який розчиняє дно та стінки. У результаті западини перетворюються на мембранні дефекти, які розвиваються за принципом «повзучих» ерозій.

У цілому до цих конформацій додаються зміни площі контакту мембрани еритроцитів не всією своєю поверхнею, а тільки дуже малою площею на вершинах шипоподібних виростів i тоді стає зрозумілою вся глибина порушення трансмембранного перенесення життєво необхідних речовин на рівні обмінної ланки гемомікроциркуляторного русла.

\section{Висновки}

Поглиблене вивчення механізмів дії фізичних навантажень стресового рівня на стан киснево-транспортної системи крові, організація гематологічного контролю на різних етапах і періодах спортивно-змагальної діяльності, а також під час проведення корекційно-відновлювальних заходів, спрямованих на усунення порушень, що виникають у результаті відхилень від оптимуму фізичної активності, - це актуальне завдання що вимагає негайного виконання.

Під час морфологічного обстеження практично в усіх студентів-спортсменів констатовано неоднорідність клітинних субпопуляцій еритроцитів. У периферійній крові, разом із нормоцитами з високою гемоглобінізацією, реєстрували субпопуляції макро- та мікроцитарних клітин. У більшості нетренованих студентів спостерігали різні морфологічні зміни форми еритроцитів, які виявляються у вигляді ехіно-, аканто- та стоматоцитозу, що свідчать про нестабільність мембран еритроцитів.

У студентів-спортсменів за впливу дозованого велоергометричного фізичного навантаження зменшувалася кількість еритроцитів, знижувалася їх осмотична та кислотна стійкість, реєстрували клітини лізису. Біохімічні дослідження показали зниження активності глюкозо-6-фосфатдегідрогенази та глутамінредуктази та вмісту відновленого глутатіону.

Виявлені морфо-біохімічні зміни свідчать про порушення структурної цілісності мембранних утворень еритроцитів і мають негативні наслідки щодо ймовірного впливу на стан здоров'я студентів-спортсменів, які поряд із навчальним навантаженням зазнають значного тренувально-змагального стресу.

\section{References}

Abdelha, M. A. K., \& Abdelmotta, S. (2010) Biochemical changes of hemoglobin and osmotic fragility of red blood cellsin high fat diet rabbits. Pakistan Journal of Biological Sciences, 13(2), 73-77.

Barker, D., Wallhead, T., \& Quennerstedt, M. (2016). Student learning through interaction in physical education. European Physical Education Review, 4, 1-6.

Bergamini, C., Gambetti, S., Dondi, A., \& Cervellati, C. (2004). Oxygen, reactive oxygen species and tissue damage. Current Pharmaceutical Design, 10(14), 1611-1626.

Bianchini, K., \& Wright, P. A. (2013). Hypoxia delays hematopoaesis: Retention of embryonic hemoglobin and erythrocytes in larval rainbow trout, Oncorhynchus mykiss, during chronic hypoxia exposure. Journal of Experimental Biology, 216(23), 4415-4425.

Brock, S. J., Rovegno, I., \& Oliver, K. L. (2009). The influence of student status on student interactions and experiences during a sport education unit. Physical Education and Sport Pedagogy, 14(4), 355-375.

Chang, Y., \& Bo, B. (2015). Effects of exhaustive exercise on the ATPsensitive potassium channel of rat cardiac sinoatrial node. Journal of Science and Medicine in Sport, 19, 65.

Chen, S., \& Nam, Y. H. (2016). Energy balance education in schools. European Physical Education Review, 4, 1-5. 
Chen, Y. L., Tseng, H. S., Kuo, W. H., Yang, S. F., Chen, D.-R., \& Tsai, H.T. (2010). Gluthation S-transferase P1 (GSTP1) gene polymorphism increase age-related susceptibility-hepatocellular carcinoma. BMC Medical Genetics, 11(46), 1-8.

Doronin, K., \& Kozlov, H. (2007). Ob urovne obshhej vynoslivosti u studentok i ego dinamike $\mathrm{v}$ techenie uchebnogo goda [On the level of general endurance of students and its dynamics during the school year]. Scientific Notes of the University named after P. F. Lesgafta, 32(10), 29-32 (in Russian).

González-Alonso, J. (2012). ATP as a mediator of erythrocyte-dependent regulation of skeletal muscle blood flow and oxygen delivery in humans. Journal of Physioljgy, 590(20), 5001-5013.

Hernayanti, H., Laksana, A. S. D., \& Aziz, S. (2015). Efekt polimorfisme gena gstp-1 terhadap aktivitas glutations-transferase (gst) pada individu terpapar logam berat timbal (Effect of GSTP-1 Gene polymorphismson glutation S-transferase (GST) activity in heavy metals lead-exposed individual). Manusia dan Lingkungan, 22(3), 305.

Holcik, M. (2001). Do mature red blood cells die by apoptosis? Trends in Genetics, 18(3), 121

Ignat'eva, S. N., \& Kubasov, R. V. (2014). Metabolicheskie adaptacionnye vozmozhnosti organizma k obucheniju studentov medicinskogo vuza na evropejskom severe [Metabolic adaptation resources of organism to studying at medical university students in european north]. Annals of the Russian Academy of Medical Sciences, 69(11-12), 84-88 (in Russian).

Jensen, F. B. (2009) The dual roles of red blood cells in tissue oxygen delivery: Oxygen carriers and regulators of local blood flow. Journal of Experimental Biology, 212(21), 3387-3393.

Kang, M. (2016). Should the physical educator be held accountable for student physical activity levels beyond physical education? Physical Education, Recreation and Dance, 87(6), 55-56.

Karaseva, E. I., \& Metelitza, D. I. (2006). Stabilization of glucoso-6phosphate dehydrogenase by its substrate and cofactor in an ultrasonic field. Journal of Bioorganic Chemistry, 32(5), 436-443.

Karle, H. (2009). Destruction of erythrocytes during experimental fever. Acta Medica Scandinavica, 186(1-6), 349-359.

Koumantakis, G. A., Watson, P. J., \& Oldham, J. A. (2005). Supplementation of general endurance exercise with stabilisation training versus general exercise only. Clinical Biomechanics, 20(5), $474-482$.

Lambert, M. I. (2016). General adaptations-exercise: Acute versus chronic and strength versus endurance training. Exercise and Human Reproduction. Springer, New York; Heidelberg Dordrecht, London.
Lorente-Catalan, E., \& Kirk, D. (2015). Student teachers understanding and application of assessment for learning during a physical education teacher education course. European Physical Education Review, 22(1), 65-81.

Mairbäurl, H. (2013). Red blood cells in sports: Effects of exercise and training on oxygen supply by red blood cells. Frontiers in Physiology, 4, 34-36.

Maroulis, S. L., Schofield, P. J., \& Edwards, M. R. (2000). The role of potassium in the response of Giardia intestinalis to hypo-osmotic stress. Molecular and Biochemical Parasitology, 108(1), 141-145.

Matarrese, P. (2005). Peroxynitrite induces senescence and apoptosis of red blood cells through the activation of aspartyl and cysteinyl proteases. FASEB Journal, 19(3), 416-418.

Mikhaylova, L. A. (2013). Central hemodynamics indices in senior pupils with increased educational and motive loading. Siberian Medical Review, 3, 55-58.

Mohanty, J. G., Nagababu, E., \& Rifkind, J. M. (2014). Red blood cell oxidative stress impairs oxygen delivery and induces red blood cell aging. Frontiers in Physiology, 5, 1-5.

Nemytov, A. A. (2007). The development of general endurance of the cadets Academy Federal Security Service at graduation courses. Uchenye Zapiski Universiteta imeni P. F. Lesgafta, 28(6), 70-73.

Ratcliffe, P. P., \& Bishop, T. (2014). Signaling hypoxia by hypoxiainducible factor protein hydroxylases: A historical overview and future perspectives. Hypoxia, 2, 197-212.

Shephard, R. J., \& Åstrand, P.-O. (2000). Endurance sports, in endurance in sport. Blackwell Science Ltd, Oxford.

Streeten, D. H. P., Speller, P. J., \& Fellerman, H. (2008). Use of corticotropininduced potassium changes in the diagnosis of both hypo- and hyperkalemic periodic paralysis. European Neurology, 33(2), 103-108.

Takahashi, M., \& Tatsugi, Y. (2013). Investigation of the attitudes of Japanese Physical Educational University students toward doping in sports. Journal of Sports Medicine and Doping Studies, 3(1), 122-125.

Tan, Y., Sun, D., Wang, J., \& Huang, W. (2010). Mechanical characterization of human red blood cells under different osmotic conditions by robotic manipulation with optical tweezers. IEEE Transactions on Biomedical Engineering, 57(7), 1816-1825.

Valbonesi, M., Garelli, S., Montani, F., Cefis, M., \& Florio, G. (2009). A simple and rapid test for the quantification of osmotic fragility of red blood cells. Acta Haematologica, 69(2), 106-110.

Zhu, X. (2015). Student perspectives of grading in physical education. European Physical Education Review, 21(4), 409-420. 